\title{
The effect of methods of surface treatment of metal elements on their surface free energy, with a view to the formation of polymer-metal hybrid elements
}

\author{
Oliwia Trzaska ${ }^{1), *)}$, Roman Wróblewski ${ }^{1}$, Alina Czekaj ${ }^{1)}$, Joanna Czy $\dot{z}^{1)}$, Jacek W. Kaczmar ${ }^{1)}$ \\ DOI: dx.doi.org/10.14314/polimery.2020.11.9
}

\begin{abstract}
An analysis was made of methods of chemical surface treatment of metal elements made of DC04 steel and Al6061 alloy, for the formation of polymer-metal joints in injection molding technology. The surface characterization included determination of surface free energy (SFE) by the OWRK (Owens-Wendt-Rabel-Kaelble) method, and determination of its polar and dispersive components. Depending on the chemical treatment applied, the highest values of the polar constant for DC04 and Al6061 sheets were 26.4 and $39.2 \mathrm{~mJ} / \mathrm{m}^{2}$, respectively, the highest values of the dispersion constant were 55.6 and $53.5 \mathrm{~mJ} / \mathrm{m}^{2}$, respectively, for DC04 and Al6061 sheets. In the case of the surfaces of sheets made of the Al6061 alloy, the increase in the polar component value was most favorably influenced by the etching with $15 \% \mathrm{NaOH}$ solution for 5 minutes, and the increase in the dispersive component - by the etching with $15 \% \mathrm{NaOH}$ solution with the addition of thiourea for 2 minutes. In the case of the surface of DC04 sheets, the increase of the polar component was most favorably influenced by chemical cleaning for 10 minutes (in a solution with the composition: $\mathrm{Na}_{2} \mathrm{CO}_{3} 50 \mathrm{~g} / \mathrm{mol}, \mathrm{Na}_{3} \mathrm{PO}_{4} \times 12 \mathrm{H}_{2} \mathrm{O} 50 \mathrm{~g} / \mathrm{mol}, \mathrm{NaOH}$ $50 \mathrm{~g} / \mathrm{mol}$ ). The highest value of the dispersive component of the surface DC04 sheets was obtained after etching with $15 \% \mathrm{HCl}$ solution with the addition of thiourea for 5 minutes.
\end{abstract}

Keywords: surface free energy (SFE), polymer-metal hybrid elements, polymer-metal interface, injection molding.

\section{Wpływ metod przygotowania powierzchni elementów metalowych na ich swobodną energię powierzchniową $w$ aspekcie wytwarzania elementów hybrydowych typu polimer-metal}

Streszczenie: Analizowano wpływ sposobu obróbki chemicznej powierzchni na właściwości adhezyjne elementów metalowych (blach) wykonanych ze stali DC04 oraz ze stopu Al6061, przeznaczonych do wytwarzania połączeń polimer-metal $w$ technologii wtryskiwania. Charakterystyka powierzchni obejmowała wyznaczenie swobodnej energii powierzchniowej (SEP) metodą OWRK (Owens-WendtRabel i Kaelble) oraz jej składowych polarnej i dyspersyjnej. W zależności od zastosowanej obróbki chemicznej największe wartości składowej polarnej SEP blach wykonanych ze stali DC04 oraz stopu Al6061 wyniosły, odpowiednio, 26,4 oraz 39,2 mJ/m², natomiast największe wartości składowej dyspersyjnej, odpowiednio, 55,6 oraz 53,5 mJ/ $\mathrm{m}^{2}$. W wypadku powierzchni blach ze stopu Al6061 na zwiększenie wartości stałej polarnej najkorzystniej wpłynęło trawienie $15 \%$ roztworem $\mathrm{NaOH}$ przez 5 minut, natomiast na zwiększenie stałej dyspersyjnej - trawienie $15 \%$ roztworem $\mathrm{NaOH}$ z dodatkiem tiomocznika przez 2 minuty. W wypadku powierzchni blach wykonanych ze stali DC04 na zwiększenie stałej polarnej najwyraźniej wpłynęło oczyszczanie chemiczne przez 10 minut (w roztworze o składzie: $\mathrm{Na}_{2} \mathrm{CO}_{3} 50 \mathrm{~g} / \mathrm{mol}, \mathrm{Na}_{3} \mathrm{PO}_{4} \times 12 \mathrm{H}_{2} \mathrm{O} 50 \mathrm{~g} / \mathrm{mol}, \mathrm{NaOH} 50 \mathrm{~g} / \mathrm{mol}$ ). Największą wartość stałej dyspersyjnej powierzchni blach ze stali DC04 uzyskano po trawieniu 15\% roztworem $\mathrm{HCl}$ z dodatkiem tiomocznika przez 5 minut.

Słowa kluczowe: swobodna energia powierzchniowa (SEP), hybrydowe elementy polimer-metal, powierzchnia międzyfazowa polimer-metal, technologia wtryskiwania.

\footnotetext{
1) Wroclaw University of Science and Technology, Department of Lightweight Elements Engineering, Foundry and Automation, Łukasiewicza 7/9, 50-371 Wrocław, Poland.

*) Author for correspondence: oliwia.trzaska@pwr.edu.pl
} 
The rapid development of the automotive and aviation industries has brought about a need to produce elements with relatively low mass and high mechanical strength [1-3]. The use of elements of high specific strength, understood as the relation of mechanical strength $\left(\mathrm{N} / \mathrm{m}^{2}\right)$ to specific gravity $\left(\mathrm{N} / \mathrm{m}^{3}\right)$, leads to reduced fuel consumption, and thereby also limits greenhouse gas emissions. If the mass of a car is reduced by $100 \mathrm{~kg}$, approximately 0.7 liters of fuel will be saved every $100 \mathrm{~km}$. Reductions in fuel consumption can be achieved by the use in the construction of land vehicles and aircraft of polymeric composite materials [4] and polymer-metal hybrid composite elements, which are usually produced by injection molding [5-8]. Injection molding technology enables the production of relatively complex hybrid elements through the joining of a metal element to a polymer in an injection process over a single technological cycle [9]. To improve the adhesion of the polymer to the metal element, various methods of surface treatment are applied: chemical or electrochemical treatment of the outer layer of the metal [8], laser structuring of the surface of metal elements to produce roughness enabling the mechanical anchoring of the injected polymer [10], or the use of an intermediate coupling layer [11].

When a joint is made between two different materials, an important phenomenon is the adhesion occurring between them, a measure of which is the work of adhesion. The work of adhesion is defined by M. Żenkiewicz [12] as the work done against the forces of adhesion being the sum of all intermolecular interactions, required to create a unit of separation surface between two phases being in equilibrium, in the course of a reversible thermal process. This is equivalent to the work that needs to be done in order to separate the adhering bodies. There exist several theories setting out the essential characteristics of work of adhesion, one of them being the theory of Owens and Wendt. Based on research carried out by Fowkes, Owens and Wendt determined a formula for the work of adhesion [ Eq. (1)], which is based on the effects of dispersive interactions as well as polar interactions: induced, orientational, hydrogen bond and acid-base $[13,14]$ :

$$
W_{a}=2 \sqrt{\gamma_{s}^{d} \gamma_{l}^{d}}+2 \sqrt{\gamma_{s}^{p} \gamma_{l}^{p}}
$$

where: $\gamma_{s}^{d}$ - the dispersive component of the surface free energy of the solid, $\gamma_{l}^{d}$ - the dispersive component of the surface free energy of the liquid, $\gamma_{s}^{p}-$ the polar component of the surface free energy of the solid, and $\gamma_{l}^{p}$ - the polar component of the surface free energy of the liquid.

Further, following Żenkiewicz's account, the surface free energy is the work required to create a unit of new surface in the course of the separation of two phases being in equilibrium, in a reversible isothermal process [12]. It is given by the following Eq. (2) [15]:

$$
\gamma=\frac{\delta W}{\delta S}\left[\frac{\mathrm{J}}{\mathrm{m}^{2}}\right]
$$

where: $\gamma$ - the surface free energy, $W$ - the work needed to create the surface, and $S$ - the created surface area.

Assuming that a drop of measuring liquid placed on a flat surface is in equilibrium, the surface free energy can be calculated from Young's Eq. (3) [16]:

$$
\gamma_{S}=\gamma_{S L}+\gamma_{L} \cos \theta\left[\frac{\mathrm{J}}{\mathrm{m}^{2}}\right]
$$

where $\gamma_{S}$ - the surface free energy of the solid, $\gamma_{S L}-$ the surface free energy of the solid-liquid interface, $\gamma_{L}-$ the surface free energy of the liquid, and $\theta-$ the contact angle.

The surface free energy ( $S F E$ ) is equal in value to the surface tension, but it has a different dimension (unit). It is dependent on the geometrical structure and certain physical properties of the materials [12].

Muhammad Akram et al. [17] investigated the surface free energy of elements made of plasma-activated polyimide to evaluate their adhesive properties in joints with titanium elements. Activation of the polyimide surfaces with plasma increased the contribution of the polar component from 36.46 to $54.41 \mathrm{~mJ} / \mathrm{m}^{2}$, and the value of the $S F E$ rose from 56.71 to $72.64 \mathrm{~mJ} / \mathrm{m}^{2}$, while the shear strength of the adhesive joints increased from 0.23 to $3.38 \mathrm{MPa}$. Depending on the method used to determine the contact angle and SFE and on the measuring liquids used, the values of the polar and dispersive components may vary $[18,19]$. Methods for determining contact angle include, among others, the bubble method, the geometrical method, and direct measurement [15]. Methods for determining SFE include Fowkes' method, the Owens-WendtRabel-Kaelble (OWRK) method, the van Oss-ChauhuryGood method, and Neumann's method [20, 21]. Example mean SFE values for the ceramic shells investigated in [20], where contact angles were determined using Wilhelmy plates, were $34.86 \mathrm{~mJ} / \mathrm{m}^{2}$ in the case of the OWRK method and $37.70 \mathrm{~mJ} / \mathrm{m}^{2}$ in the case of Fowkes' method. When contact angles were determined by the sessile drop technique, the respective SFE values were 36.82 and $40.07 \mathrm{~mJ} / \mathrm{m}^{2}$.

Adhesive properties may be evaluated using traditional measuring liquids [22, 23]; alternatively, in the case of polymer-metal joints, the wettability of the surface of the metal element may be analyzed directly by applying drops of liquid polymer. Xiping Li et al. [24] conducted tests, in a nitrogen atmosphere, to determine how the temperature of an aluminum alloy mold insert affected the contact angle of polypropylene. They found that when the temperature of the metal element was increased from $170^{\circ} \mathrm{C}$ to $210^{\circ} \mathrm{C}$, the contact angle of polypropylene on the surface was reduced by over $50 \%$.

In the present work, it was investigated how the method of preparing the surface of metal elements affects the SFE and the values of the polar and dispersive components.

In the experiments, the surfaces of the metal elements were prepared, the contact angles were measured using 


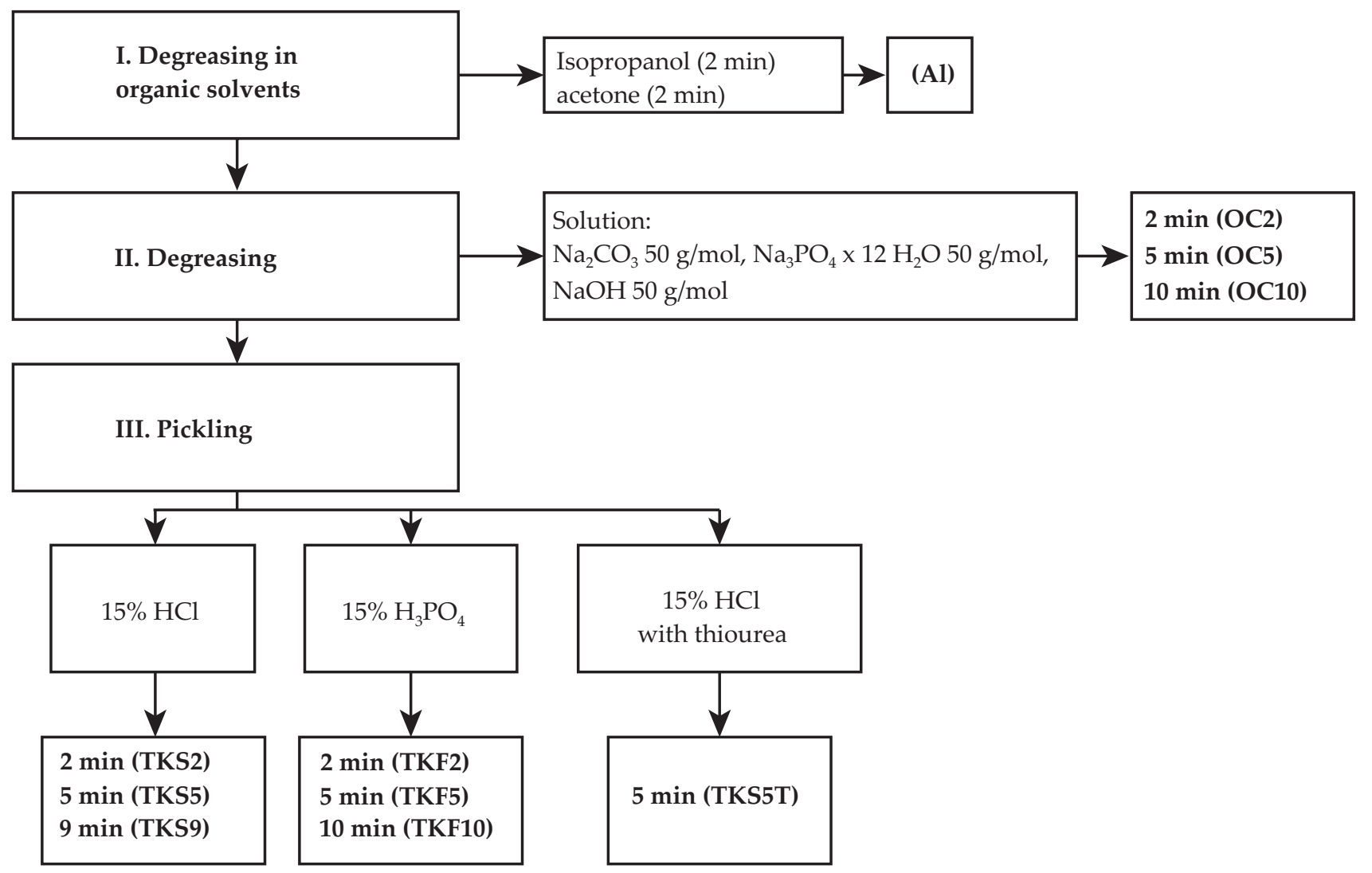

Fig. 1. Block diagram of methods of surface preparation of elements made of DC04 steel (labels of corresponding series of samples are given in parentheses)

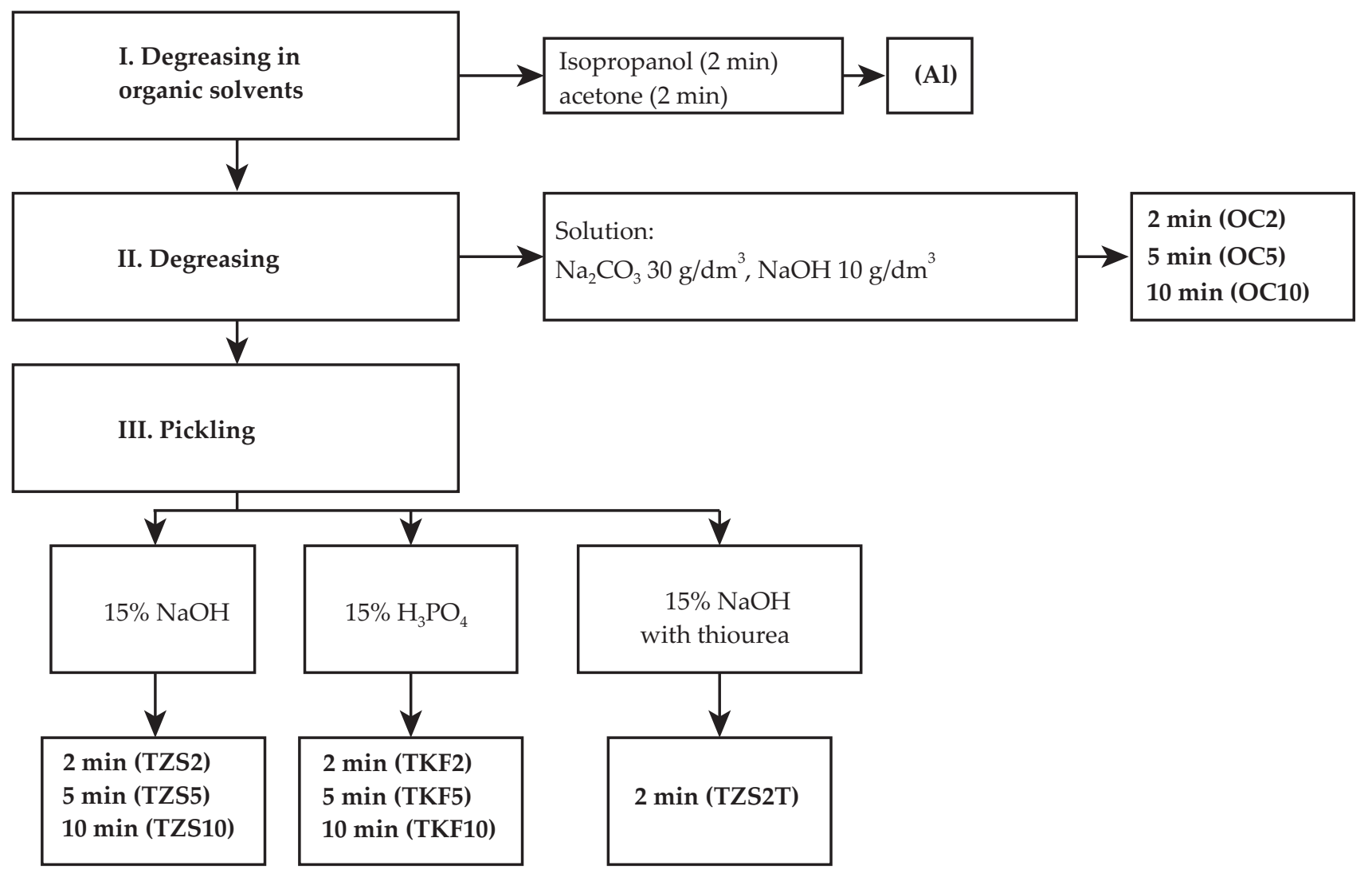

Fig. 2. Block diagram of methods of surface preparation of elements made of Al6061 alloy (labels of corresponding series of samples are given in parentheses) 
selected measuring liquids, and the surface free energy was determined.

\section{EXPERIMENTAL PART}

\section{Materials}

Surface free energy (SFE) was investigated using elements made of DC04 steel (cold-formed, low-carbon structural steel sheet) with the composition $C \leq 0.08 \%$, $\mathrm{Mn} \leq 0.4 \%, \mathrm{P} \leq 0.03 \%, \mathrm{~S} \leq 0.03 \%$ [25], and elements made of Al6061 aluminum alloy, with the composition $\mathrm{Mg}=$ $0.80-1.20 \%, \mathrm{Mn} \leq 0.15 \%, \mathrm{Fe} \leq 0.70 \%, \mathrm{Si}=0.40-0.80 \%, \mathrm{Cu}=$ $0.15-0.40 \%, \mathrm{Zn} \leq 0.25 \%, \mathrm{Cr}=0.04-0.35 \%, \mathrm{Ti} \leq 0.15 \%$, others $\leq 0.05 \%$, others total $\leq 0.15 \%$, remainder $\mathrm{Al}[26]$.

\section{Methods of surface preparation}

For both types of metal elements, three methods of surface preparation were tested:

I - degreasing in organic solvents;

II - degreasing in organic solvents followed by chemical degreasing;

III - degreasing in organic solvents followed by chemical degreasing and chemical treatment by pickling (Figs. 1 and 2).

The surface treatment processes were carried out at room temperature, using aqueous solutions of selected chemical reagents. Samples were rinsed with deionized water following chemical degreasing and after the pickling processes. In the case of DC04 steel samples, after pickling they were neutralized with ammonia solution before being rinsed with deionized water.

\section{Methods of testing}

Contact angles were measured with a goniometer from Kruss HMT GmbH, using the sessile drop technique. Four measuring liquids were used (Table 1): distilled water, diiodomethane, ethylene glycol, formamide [27-29].

Knowing the contact angles, the surface free energy (SFE) was computed by the OWRK (Owens-WendtRabel-Kaelble) method. This takes account of the dispersion and polar constants of surface free energy, and requires solving Eq. (4) for a given measuring liquid:

$$
\underbrace{\frac{(1+\cos \theta) \sigma_{l}}{2 \sqrt{\sigma_{l}^{D}}}}_{\mathrm{y}}=\underbrace{\sqrt{\sigma_{s}^{P}}}_{\mathrm{m}} \underbrace{\sqrt{\frac{\sigma_{l}^{P}}{\sigma_{l}^{D}}}}_{\mathrm{x}}+\underbrace{\sqrt{\sigma_{s}^{D}}}_{\mathrm{b}}
$$

where: $\theta$ - the contact angle, $\sigma_{l}$ - the surface free energy of the liquid, $\sigma_{l}^{D}$ - the dispersive component of the surface free energy of the liquid, $\sigma_{s}^{P}-$ the polar component of the surface free energy of the solid, $\sigma_{l}^{P}-$ the polar component of the surface free energy of the liquid, and $\sigma_{s}^{D}$ - the dispersive component of the surface free energy of the solid.

For each liquid, the values $\mathrm{x}$ and $\mathrm{y}$ were determined, and respective diagrams were constructed on that basis. To determine values between points a trend line was used, which indicated the values $\mathrm{m}$ and $\mathrm{b}$, namely the polar and dispersive components of the surface free energy.

\section{RESULTS AND DISCUSSION}

Figures 3 and 4 show bar charts of the surface free energy (SFE), broken down into polar and dispersive components.

For both types of metal elements (those made from DC04 steel and those made from Al6061 alloy) the highest values of the dispersive component were obtained for surfaces prepared by pickling with the addition of a corrosion inhibitor (thiourea). For the Al6061 elements the dispersion constant was $53.5 \mathrm{~mJ} / \mathrm{m}^{2}$, while for the steel elements it was $55.6 \mathrm{~mJ} / \mathrm{m}^{2}$. Values of the polar constant were found to be relatively low (in comparison with the other results), amounting to $21.3 \mathrm{~mJ} / \mathrm{m}^{2}$ for elements made of Al6061 alloy, and $8.6 \mathrm{~mJ} / \mathrm{m}^{2}$ for those made of DC04 steel.

Analyzing the remaining surface treatment methods, for the Al6061 alloy elements, relatively high values of the dispersion constant were also found following treatments OC10 and OC5 (chemical degreasing for 10 and 5 minutes) and for surfaces that had been pickled in a $15 \%$ solution of $\mathrm{NaOH}$ for 2 minutes. These values were above $50.0 \mathrm{~mJ} / \mathrm{m}^{2}$. A longer time of pickling in alkaline solutions led to a reduction in the value of the dispersion constant (to below $40.0 \mathrm{~mJ} / \mathrm{m}^{2}$ ). Pickling in $15 \%$ solutions of phosphoric acid resulted in dispersion constants in the range $46.9-48.8 \mathrm{~mJ} / \mathrm{m}^{2}$. For the steel elements, an increase in the dispersion constant was observed following all pickling

$\mathrm{T}$ a b 1 e 1. Surface tensions of liquids and their components [27-29]

\begin{tabular}{l|c|c|c|c}
\hline \multicolumn{1}{c|}{ Parameter } & Distilled water & Diiodomethane & Ethylene glycol & Formamide \\
\hline Dispersive component, $\mathrm{mJ} / \mathrm{m}^{2}$ & 19.9 & 47.4 & 30.1 & 23.5 \\
Polar component, $\mathrm{mJ} / \mathrm{m}^{2}$ & 52.2 & 2.6 & 18.2 & 33.4 \\
Surface tension, $\mathrm{mJ} / \mathrm{m}^{2}$ & 72.1 & 50 & 47.7 & 56.9 \\
\hline
\end{tabular}




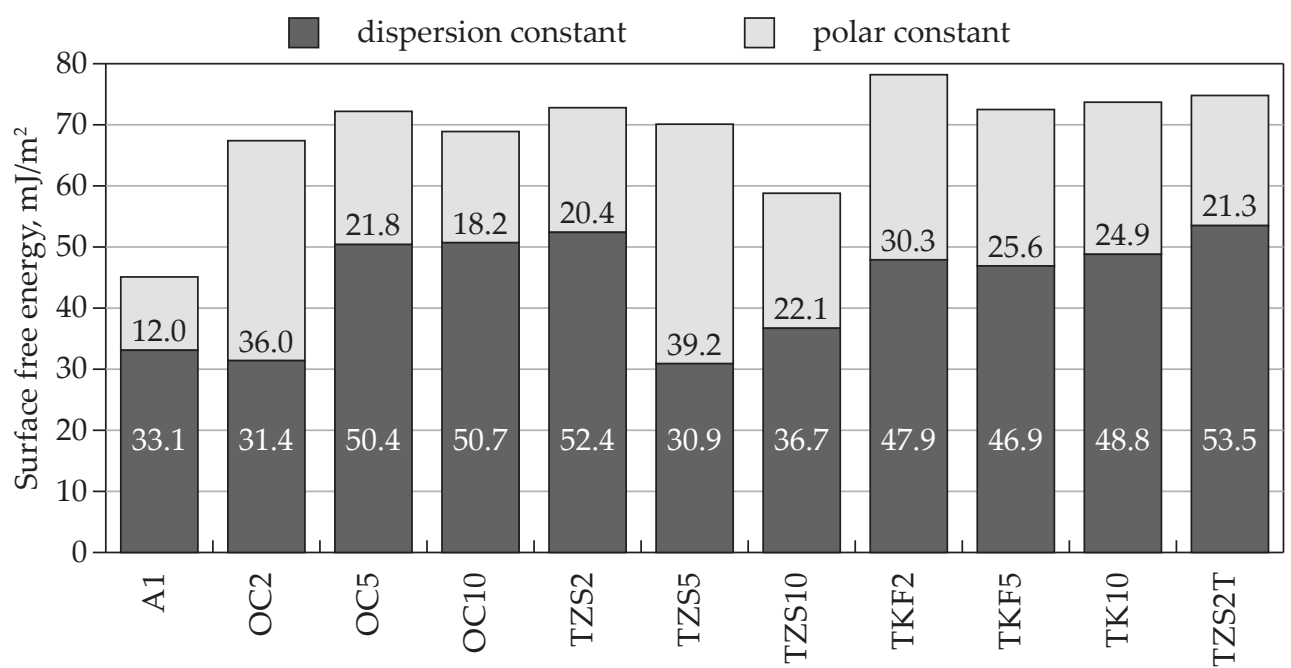

Fig. 3. Effect of surface treatment of metal elements made of Al6061 alloy on their surface free energy

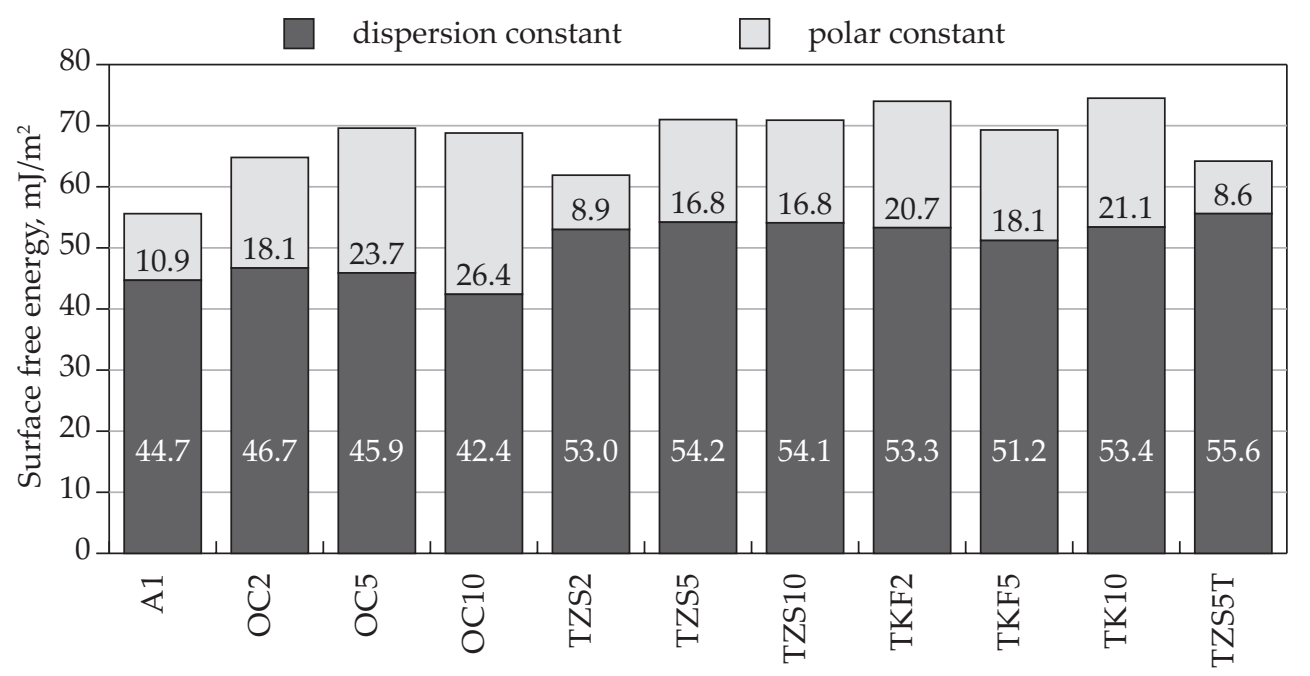

Fig. 4. Effect of surface treatment of metal elements made of DC04 steel on their surface free energy

treatments (in 15\% solution of hydrochloric acid or phosphoric acid). However, only in the case of pickling for 2 minutes in $15 \%$ hydrochloric acid was the value of the polar constant also relatively low.

\section{CONCLUSIONS}

A reduction in the value of the polar constant, accompanied by an increase in the dispersion constant, favors improved adhesion at the polymer-metal interface. In hybrid systems, the injected polymer has a mainly nonpolar structure (in contrast to the surface of the metal elements), which hinders mutual interaction at the interface between the two materials and reduces their adhesion. It is therefore appropriate to apply surface treatments with the aim of reducing the polar constant of the surface of metal elements used as mold inserts in polymer-metal hybrid systems.
In this study, the highest values of the dispersion constant were obtained following chemical treatment using thiourea as a corrosion inhibitor. The high dispersion constant of the metal element surfaces can be expected to provide a suitable environment for the formation of joints with polymers having low surface energy, such as polyolefins. Analogously, joints with polymers containing polar groups in their structure, such as polyamides, should be made using metal surfaces with an increased contribution of the polar constant.

This work was conducted under research project no. 2016/21/B/ ST8/03152, "Evaluation of the process of constitution of a joint at a metal-polymer interface using flow markers and the methods of active infrared thermography, holographic vibrometry and shearography", funded by the National Science Centre in Kraków and carried out jointly by Poznań University of Technology and Wroclaw University of Science and Technology. 


\section{REFERENCES}

[1] Li S.M., Xu K., Wang J.R.: Modern Mechanical Engineering 2018, 8, 192.

https://doi.org/10.4236/mme.2018.83013

[2] Sattel M.: Lightweight Design worldwide 2018, 11, 36. https://doi.org/10.1007/s41777-017-0058-5

[3] Luk J.M., Kim H.C., De Kleine R.D. et al.: Transportation Research Part D: Transport and Environment 2018, 62, 1. https://doi.org/10.1016/j.trd.2018.02.006

[4] Subadra S.P., Yousef S., Griskevicius P., Makarevicius V.: Polymer Testing 2020, 86, 106480. https://doi.org/10.1016/j.polymertesting.2020.106480

[5] Faruk O., Tjong J., Sain M.: "Lightweight and Sustainable Materials for Automotive Applications", CRC Press, Boca Raton 2017, p. 454.

[6] Kühnert I., Maenz T., Rösner J., Schneider K.: "Assembly Injection Molding and Testing of Polymer-Metal-Hybrids", materials of ANTEC 2012: 70th Annual Technical Conference of the Society of Plastics Engineers, Orlando, Floryda USA, 2-4 April 2012, pp.1388-1393.

[7] Vittinghoff J., Drummer D.: “Investigating the FullFace Joining of Polymer-Metal Hybrid Structures", materials of ANTEC 2014: 72th Annual Technical Conference of the Society of Plastics Engineers, Las Vegas, Nevada, USA, 28-30 April 2014, pp. 17951800.

[8] Kleffel T., Drummer D.: Journal of Polymer Engineering 2018, 38, 675. https://doi.org/10.1515/polyeng-2017-0432

[9] Hopmann C., Schild J., Wurzbacher S. et al.: Journal of Polymer Engineering 2018, 38, 583. https://doi.org/10.1515/polyeng-2017-0354

[10] Hoffmann L., Faißt B., Kose K., Eggers F.: Lightweight Design worldwide 2017, 10, 44. https://doi.org/10.1007/s41777-017-0014-4

[11] Li L., Sun L., Dai Z. et al.: Journal of Materials Processing Technology 2019, 263, 385. https://doi.org/10.1016/j.jmatprotec.2018.08.039

[12] Żenkiewicz M.: „Adhezja i modyfikacja warstwy wierzchniej tworzyw wielkocząsteczkowych", Wydawnictwa Naukowo-Techniczne, Warszawa 2000.

[13] Awaja F., Gilbert M., Kelly G. et al.: Progress in Polymer Science 2009, 34, 948. https://doi.org/10.1016/j.progpolymsci.2009.04.007

[14] Rudawska A.: „Wybrane zagadnienia konstytuowania połączeń adhezyjnych jednorodnych i hybrydowych", Politechnika Lubelska, Lublin 2013, p. 27.

[15] Barnat-Hunek D.: „Swobodna energia powierzchniowa jako czynnik kształtujący skuteczność hydro- fobizacji w ochronie konstrukcji budowlanych", Politechnika Lubelska, Lublin 2016, pp. 28, 30.

[16] Baldan A.: International Journal of Adhesion and Adhesives 2012, 38, 95.

https://doi.org/10.1016/j.ijadhadh.2012.04.007

[17] Akram M., Bhowmik S., Jansen K.M.B., Ernst Leo J.: "Surface modification of polyimide by atmospheric pressure plasma for adhesive bonding with titanium and its application to aviation and space", materials of SAMPE 2010 - New Materials and Processes for a New Economy, Seattle WA, USA, 17-20 May 2010, pp. 326-335.

[18] Żenkiewicz M.: Polimery 2005, 50, 365. http://dx.doi.org/10.14314/polimery.2005.365

[19] Firlik S., Molenda J., Borycki J.: Chemik 2010, 64, 238. http://yadda.icm.edu.pl/yadda/element/bwmeta1.element.baztech-article-BPP1-0098-0016?q=bwmeta1. element.baztech-volume-0009-2886-chemik-2010vol__64_nr_4;2\&qt=CHILDREN-STATELESS.

[20] Rogowska R.: Problemy Eksploatacji 2013, 1, 85. https://www.infona.pl/resource/bwmeta1.element. baztech-95b2b8ce-98c5-4530-8977-8ceb7712bc07.

[21] Żenkiewicz M.: Polimery 2007, 52, 760. http://dx.doi.org/10.14314/polimery.2007.760

[22] Bañon F., Sambruno A., Batista M. et al.: Metals 2020, 10, 290. https://doi.org/10.3390/met10020290

[23] Ghanbari A., Attar M.M.: Surface and Coatings Technology 2014, 246, 26. https://doi.org/10.1016/j.surfcoat.2014.02.057

[24] Li X., Gong N., Yang C. et al.: Journal of Materials Processing Technology 2018, 255, 635. https://doi.org/10.1016/j.jmatprotec.2018.01.008

[25] http://kbhakord.pl/pl/stal-informator-techniczny (access date 13.04.2020).

[26] http://www.emetal.eu/aluminium/aluminium-EN-AW-6061-ISO_-AlMg1SiCu-EN_-AW-AlMg1SiCuPN_-PA-45-DIN_-AlMg1SiCu-wnr_-3.3211/(access date 13.04.2020).

[27] Bellon-Fontaine M.N., Mozes N., van der Mei H.C. et al.: Cell Biophysics 1990, 17, 93. https://doi.org/10.1007/BF02989805

[28] Busscher H.J., van Pelt A.W.J., de Boer P. et al.: Colloids and Surfaces 1984, 9 (4), 319. https://doi.org/10.1016/0166-6622(84)80175-4

[29] Jie-Rong C., Wakida T.: Journal of Applied Polymer Science 1997, 63, 1733. h t t p s://doi.org/10.1002 / ( S I C I) 1097 4628(19970328)63:13<1733::AID-APP4>3.0.CO;2-H

Received 20 III 2020. 